\title{
Tall and short-sized elephant grass genotypes: morphophysiological aspects cut-and-carry, and grazing management
}

\section{Pedro Henrique Ferreira da Silva ${ }^{1 *}$ (D) Tafnes Bernardo Sales ${ }^{1}$ Maikon Figueredo Lemos ${ }^{1}$ Maria da Conceição Silva ${ }^{2}$ Robson Elpidio Pereira Ribeiro ${ }^{1}$ Mércia Virginia Ferreira dos Santos $^{1}(\mathbb{D}$ Alexandre Carneiro Leão de Mello ${ }^{1}$ Márcio Vieira da Cunha ${ }^{1}(\mathbb{D}$}

${ }^{1}$ Universidade Federal Rural de Pernambuco (UFRPE), 52171-900, Recife, PE, Brasil. E-mail: pehenrique1709@gmail.com. "Corresponding author. ${ }^{2}$ Instituto Agronômico de Pernambuco (IPA), Recife, PE, Brasil.

ABSTRACT: Elephant grass (Pennisetum purpureum SCHUm.) has been grown only in cut-and-carry systems for a long time. However interest in its grazing management has been increasing because of the selection of short-sized genotypes, which have gained new relevance since 1988 with the registration of 'Mott' grass. In this sense, tall and short-sized genotypes present important differences in morphology, quality and productivity; although, environmental factors also exert influence on these aspects. This review aimed to approach how the elephant grass size can influence the morphophysiological characteristics, management decisions, and exploitation of this species. The morphophysiological aspects and the elephant grass sizes are important to direct their utilization in the different production systems. The research results from previous decades suggest that the particularities of the tall-sized genotypes, such as great forage accumulation, high organic reserves content, and stem elongation, favor their management in cut-and-carry systems and industrial sectors. Conversely, the shortsized elephant grass genotypes present aspects as higher leaf proportion in the harvested forage, leaf/stem ratio, and tillering. These factors facilitate their exploitation in grazing systems.

Keywords: canopy, fertilization, irrigation, genotype size, Pennisetum purpureum.

Capins-elefante de porte alto e baixo: aspectos morfofisiológicos, manejo do pastejo e de capineiras

RESUMO: O capim-elefante (Pennisetum purpureum SCHUM.) foi durante muito tempo cultivado apenas em capineiras. Porém, o interesse pelo seu manejo sob pastejo vem aumentando por conta da seleção de genótipos de porte baixo, que ganhou nova relevância a partir de 1988 , com o registro do capim Mott. Neste sentido, genótipos de porte alto e baixo apresentam diferenças morfológicas, produtivas e qualitativas importantes, mesmo que fatores ambientais também exerçam influência sob estes aspectos. O objetivo desta revisão foi abordar como o porte do capim-elefante pode influenciar características morfofisiológicas, decisões de manejo e formas de utilização da espécie. Os aspectos morfofisiológicos e o porte do capim-elefante são importantes para direcionar sua utilização nos diferentes sistemas de produção. Os resultados de pesquisa das últimas décadas sugerem que as particularidades dos genótipos de porte alto, como elevado acúmulo de forragem, reservas orgânicas e alongamento dos colmos favorecem seu manejo sob corte e sua utilização em setores industriais. Já o capim-elefante de porte baixo apresenta aspectos como elevada proporção de folhas na forragem colhida, alta relação folha: colmo e elevado perfilhamento. Estes fatores facilitam sua utilização em sistemas de produção a pasto.

Palavras-chave: adubação, dossel forrageiro, porte do genótipo, irrigação, Pennisetum purpureum.

\section{INTRODUCTION}

Elephant grass (Pennisetum purpureum Schum.) is one of the most important forage grasses for Brazilian livestock production, and it is grown in tropical, subtropical, and even semiarid regions (SINGH, 2013; PEREIRA et al., 2017). The species, for which the origin is tropical Africa, presents a considerable number of genotypes, classified into five large well-defined morphological groups: Cameroon, Napier, Merker, Dwarf, and Specific Hybrids (SIGNH, 2013).

Currently, size is an elephant grass trait that has been stood out in scientific studies (CUNHA et al., 2011; PEREIRA et al., 2017; VIANA et al., 2018). The tall genotypes are widely grown in cut-and-carry 
systems due to their high forage productivity, which is related to characteristics including stem elongation and proportion in the harvested forage (VIANA et al., 2015). However, the species has great variability in its germplasm, so there is the possibility of genotype selection with desirable characteristics according to the production system or the manner of exploitation. Thus, the selection and use of short-sized elephant grass have gained relevance in the last decades (WILLIAMS \& HANNA, 1995; VIANA et al., 2015; SOUZA et al., 2017). The dwarf elephant grass often presents a greater leaf/stem ratio (LSR) and provides better grazing efficiency by animals than tall-sized elephant grass genotypes (CUNHA et al., 2007).

However, the interaction with the environment also can modify morphological aspects of elephant grass via adaptation mechanisms of the plant. Elephant grass presents wide phenotypic plasticity within the various types of management, exploitation, and interaction with the environment (GOMIDE et al., 2015). Therefore, aspects such as tillering, organic reserves, and residual leaf area index (LAI) significantly affect the forage quality and production, in addition to the crop being perennial (LIRA et al., 2010); and consequently, these factors can influence the utilization methods. Thus, plant morphological characterization can be decisive for successful management. Based on this context, this review aimed to draw a panorama of the effects of the different sizes of elephant grass on its morphophysiological aspects, management, and manners of exploitation.

\section{Tall-sized elephant grass}

The tall-sized elephant grasses have common morphological patterns among each other, such as the elongation of the internodes (Figure 1) that results in long stem lengths. This fast elongation has a significant influence on the high forage productivity of these genotypes (PEREIRA et al., 2017). In this sense, VIANA et al. (2018) found average internode lengths of 10.6 and $4.7 \mathrm{~cm}$ from 'Elephant B' and 'Taiwan A-146 2.37', which are tall and short-sized genotypes, respectively. Conversely, VIANA et al. (2015) did observe greater forage mass in 'Elephant B' pastures $\left(3,080 \mathrm{~kg} \mathrm{ha}^{-1}\right)$ compared to pastures of 'Taiwan A-146 2.37', for which the average forage mass was $2,180 \mathrm{~kg} \mathrm{ha}^{-1}$.

The tall-sized genotypes also present a thick stem diameter because of their great cell wall thickness composed of lignified vessels and sclerenchyma tissues (SANCHÊS et al., 2018), which is responsible for the plant's physical sustention. BUDIMAN et al. (2012) compared the stem diameter of 'King' grass (tallsized, belongs to Napier group) to 'Mott' grass (belongs to Dwarf group) and related the superiority of the 'King' cultivar (1.35 against $1.05 \mathrm{~cm}$ to 'Mott' grass).

Moreover, the proportion of morphological components in tall-sized genotypes is different in comparison to that of short-sized grasses. In general, there are more dead or senescent materials and a lower percentage of leaf blades (QUEIROZ et al., 2000; GOMIDE et al., 2015; SOUZA et al., 2017), which can be explained by the great proportion of basilar tillers of these genotypes, because basal tillers tend to present higher senescence rate compared to aerial tillers (PACIULLO et al., 2003). SOUZA et al. (2017) observed a leaf blade (LB) proportion of $29.50 \%$ and a dead material (DDM) proportion of $29.67 \%$ in the tall-sized genotype 'CNPGL 96-273 '. Conversely, for the short-sized genotype 'CNPGL 96-24-1', the proportion was $45.80 \%$ for LB and only $0.60 \%$ for DDM. This reflected the better nutritional value of the short genotype, in which the dry matter digestibility was $643.5 \mathrm{~g} \mathrm{~kg}^{-1}$, against only $569.2 \mathrm{~g}$ $\mathrm{kg}^{-1}$ for the tall genotype.

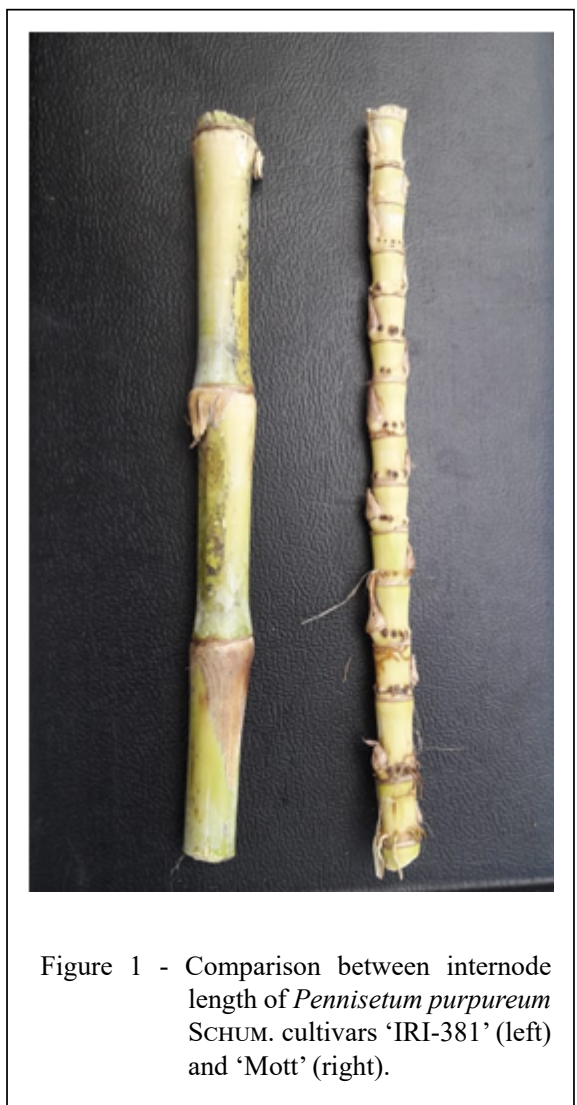

Ciência Rural, v.51, n.9, 2021. 
Another morphophysiological aspect that is important to grasses is the organic reserve. The partition of organic molecules such as starch and saccharide depends on a source-drain ratio that occurs from the roots or the base of stems to leaves (TAIZ et al., 2017). Although, this dynamic is influenced by defoliation management and edaphoclimatic conditions (GOMIDE et al., 2015), it is possible to consider that there exists a difference between the organic reserves of tall and short-sized elephant grass genotypes.

SILVA et al. (2015) evaluated the root chemical composition of tall-sized 'IRI-381' genotype grazing by Holstein $\times$ Zebu heifers. The authors observed an average $\mathrm{N}$ content of only $9.52 \mathrm{~g} \mathrm{~kg}^{-1} \mathrm{OM}$, while the average $\mathrm{C}$ content was quite higher, $338.5 \mathrm{~g} \mathrm{~kg}^{-1}$ OM. RIBEIRO (2019) did observe greater non-fiber carbohydrate content (NFC) in the stem base for the tall-sized genotype 'Elephant B' (221.3 $\mathrm{g} \mathrm{kg}^{-1} \mathrm{DM}$ ) compared to 'Taiwan A-146 2.37', which was only $180.1 \mathrm{~g} \mathrm{~kg}^{-1} \mathrm{DM}$. This is because tall genotypes have deeper roots than shortsized genotypes, besides having thicker stems and denser and wider clumps (ALENCAR et al. 2009). These factors suggested that tall-sized elephant grass genotypes, in most cases, can present more organic reserves than short-sized clones.

All these factors explain several of the known attributes of tall-sized elephant grass genotypes, such as higher production and dry matter content (RIBEIRO, 2019), higher basal tillering, and lower bulk density (CUNHA et al., 2011). Such attributes allow more harvests per year and favor manual harvest. Therefore, the tall-sized genotypes are rather common in cutand-carry systems (SINGH, 2013), although, these clones can also be managed in grazing systems.

\section{Short-sized elephant grass}

The interest to use dwarf genotypes in livestock has been renewed considerably in recent decades, especially after the 'Mott' grass registration in 1988 (SOLLENBERG, 1989; WILLIAMS \& HANNA, 1995). The clones of the Dwarf group present morphological characteristics and canopy structure, in addition to production and forage quality that are desirable for grazing management. The high proportion of leaves favor this grazing management without compromising the forage mass production (SINGH, 2013).

The short-sized elephant grass presents a low stem proportion and a high percentage of leaves (Table 1), besides a larger number of short internodes compared to tall-sized genotypes (PEREIRA et al., 2017). Such particularities reflect the higher LSR, number of leaves per tiller (NLT), lower plant height, and greater bulk density (GOMIDE et al., 2015). All these factors contribute to a better nutritional value and grazing efficiency by the animals (ANDRADE et al., 2016).

The leaf area index (LAI) is also an important morphophysiological aspect of grazing management because it reflects the vegetal growth dynamic. The LAI is a dimensionless variable that represents the area that one leaf blade face of a canopy occupies relative to the soil (GASTAL \& LEMAIRE, 2015). In this sense, the tiller density (TL), NLT and the final lengths of leaves directly influence the LAI. However, considering the LAI in tropical grass canopies, the LSR is another aspect that extensively modifies the LAI (DA SILVA \& NASCIMENTO JÚNIOR, 2007). Thus, considering that dwarf elephant grass canopies present higher LSR, NLT, and TD values than tall-sized elephant grass canopies, they may also present higher LAI values under the same management and edaphoclimatic conditions. CUNHA et al. (2011) observed an LAI of 2.8 for the canopies of short-sized clones 'Mott' and 'Taiwan A-146 2.114' under cut-and-carry management, while the values reported for the tall-sized 'Elephant B' and 'IRI-381' were only 2.3 and 2.2 , respectively.

In the scientific studies of recent decades (Table 1), the productive and morphological characteristics of elephant grass have been a target of research. The worldwide results obtained in the last 25 years reinforce the differences between tall and shortsized elephant grass genotypes related to morphology and forage productivity, despite the particularities of each study such as the method of use, locale, and defoliation frequency and intensity, in addition to environmental factors. In the sequence of this review, the possible implications that the different sizes of the genotypes can have concerning the principal aspects of elephant grass management were approached.

\section{Cut-and-carry system management}

In a cut-and-carry system, the forage is harvested by mechanical or manual cutting and offered to the animals, or used for ensilage (SINGH, 2013). In this situation, this defoliation management presents some advantages over grazing management: (i) the growth and management occur in reduced arable areas of the farm; (ii) there is great forage accumulation because of the total tissue renewal; (iii) there are lower forage losses and higher forage use efficiency (SINGH, 2013). However, some implications also should be considered: (i) the harvest and the animal feed can increase the production cost; 
Table 1 - Forage mass, morphological composition, and leaf/stem ratio of elephant grass genotypes in scientific studies carried out in the last 25 years (general average results of each experiment).

\begin{tabular}{|c|c|c|c|c|c|c|}
\hline Reference & Country & Grass size & $\mathrm{FM}^{1}\left(\mathrm{~kg} \mathrm{ha}^{-1}\right)$ & \multicolumn{3}{|c|}{ Morphological composition } \\
\hline & & & & $\mathrm{LB}^{2}(\%)$ & $S^{3}(\%)$ & $\mathrm{LSR}^{4}$ \\
\hline WILLIAMS \& HANNA (1995) & $\mathrm{EUA}^{5}$ & Short & 2331 & 92.00 & 8.50 & 11.50 \\
\hline QUEIROZ FILHO et al. (1998) & Brazil & Tall & 8582 & 46.13 & 53.84 & 0.87 \\
\hline QUEIROZ FILHO et al. (2000) & Brazil & Tall & 5793 & 53.16 & 46.83 & 1.21 \\
\hline CARVALHO et al. (2005) & Brazil & Tall & 4291 & 32.56 & 35.78 & 0.91 \\
\hline ZEWDU (2008) & Ethiopia & Tall & 4240 & 51.85 & 48.17 & 1.13 \\
\hline JORGENSEN et al. (2010) & Thailand & Short & 2924 & 73.00 & 20.15 & 3.62 \\
\hline BUDIMAN et al. (2012) & India & Short & 1790 & - & - & 9.24 \\
\hline GOMIDE et al. (2015) & Brazil & Short & - & 49.70 & 42.20 & 1.34 \\
\hline KEBEDE et al. (2016) & Ethiopia & Short & 2451 & - & - & 2.37 \\
\hline DOURADO et al. $(2019)^{6}$ & Brazil & Tall & 13029 & 21.30 & 24.21 & 0.88 \\
\hline
\end{tabular}

${ }^{1}$ Forage mass basis in the dry matter content $\left(\mathrm{kg} \mathrm{ha}{ }^{-1} \mathrm{DM}\right) ;{ }^{2}$ Leaf blades; ${ }^{3} \mathrm{Stems} ;{ }^{4} \mathrm{Leaf} /$ stem ratio; ${ }^{5}$ United States of America; ${ }^{6}$ Forage mass only of the leaf blades.

and (ii) can reduce nutrient cycling due to the low amount of litter deposition (LIU et al., 2011).

For adequate cropping in the cut-andcarry systems, the relief should be flat or slightly undulating to minimize soil erosion and favor ease of labor, due to the erect growth habit of elephant grass. Fertilization and irrigation are desirable; although, they are dependent on the technological degree of the farmer, in addition to the climate conditions and water availability (ALENCAR et al., 2009).

The propagation of elephant grass is vegetative, with the stems being planted in furrows or holes. Thus, the axial meristems generate new shoots that initially compound the canopy. However, the dominance of apical meristems should be considered, because they hamper the development of the axial gem due to auxin concentration (TAIZ et al., 2017). If they do not develop appropriately, there can be failures in the canopy formation. Considering this, the planting should be "overlaid", that is, one stem should overlap the previous in its final third to avoid apical dominance damaging the plant population (LIRA et al., 2010). RIBEIRO (2019) did observe that the complete establishment of 'Elephant B' and 'IRI381 ' (tall-sized genotypes) occurred at 60 days after planting, compared to 68 and 71 days for 'Taiwan A-146 2.37' and 'Mott' grass, respectively. The shoot percentages were also higher for the tall-sized (94\%) than for the short-sized clones (89\%). Despite that, the establishment of the four genotypes was satisfactory at 90 days after planting under irrigation.
The basilar tillering is another important aspect of tall-sized genotypes for cutting management. A greater number of basilar rather than aerial tillers allows a greater forage mass and accumulation because this type of tiller often is heavier and provides a vertical growth of plant compared to the aerial tillers (FERNANDES et al., 2016). SILVA et al. (2010) evaluated the number of basilar and aerial tillers from 54 tall-sized elephant grass clones under manual cutting and observed an average of 27 basilar tillers and only 3 aerial tillers per linear meter. These results were because of the high basilar tillering capacity of tall-sized genotypes, and to the high defoliation intensity (at ground level) that eliminated the apical gems and avoided the axillary tillering. In this sense, a general harvest recommendation in cut-and-carry systems is between 60 and 90 days of re-growth for adequate forage accumulation and nutritional value (VALADARES FILHO et al., 2016). At this point, the plant height will vary from 150 to $400 \mathrm{~cm}$, considering the wide variability of the tallsized elephant grass genotypes, especially the new cultivar 'BRS Capiaçu' (PEREIRA et al., 2017).

In this defoliation management, the re-growth capacity is much more dependent on the organic reserves than residual LAI. For the concentration of these carbohydrates in the base of the stems and plant crown, genotypes in the Cameroon group present important advantages because of their thick stems and big clumps (SINGH, 2013). It is worth mentioning that 'Mott' grass also presents

Ciência Rural, v.51, n.9, 2021. 
these qualities, despite being a short-sized genotype (ANDRADE et al., 2016). RIBEIRO (2019) did observe greater NFC content in the base of stems of 'Mott' grass (248.1 $\mathrm{g} \mathrm{kg}^{-1}$ ) compared to 'IRI-381' $\left(200.1 \mathrm{~g} \mathrm{~kg}^{-1}\right)$.

\section{Grazing management}

Grasslands are ecosystems composed of interacting abiotic and biotic factors. Within the biotic factors are the soil microbiota, the forage plants, and the grazers, mainly the ruminants (TEAGUE, 2018). Conversely, the abiotic factors are edaphoclimatic aspects such as rainfall, temperature, and soil characteristics (LEMAIRE et al., 2011). Thus, some morphological and structural aspects should be considered in elephant grass grazing management. Considering the erect growth habit of this forage grass, its management under continuous stocking is not recommended because in this scenario, the apical meristem is quite exposed, and if it is removed several times it can lead to plant death and pasture degradation (PEDREIRA, 2013). Moreover, erect forage plants are not resistant to excessive animal trampling and need rest periods to recover from this type of damage (SOLLENBERGER et al., 2020). Therefore, intermittent stocking is more suitable for elephant grass grazing management.

In Brazil, the grazing management criteria of critical LAI, when the canopy reaches $95 \%$ light interception, has also been adopted for elephant grass (CARVALHO et al., 2005; GOMIDE et al., 2015). The entrance of the animals in paddocks is considered ideal at this point, because the live leaf proportion is possibly the highest, while the percentage of senescent material is the lowest. Therefore, considering the tall-sized genotypes, a general recommendation of the suitable entrance moment of the animals at the paddocks is given when the forage canopy reaches about $100 \mathrm{~cm}$ of height (DA SILVA \& NASCIMENTO JÚNIOR, 2007). The post-grazing residue can vary from 40 to 50 cm (CARVALHO et al., 2005). Conversely, for the short-sized elephant grass genotypes, these values can be 70 and $30 \mathrm{~cm}$, on average, respectively, at pre- and post-grazing (VIANA et al., 2015; VIANA et al., 2018). Nevertheless, it is worth pointing out that the edaphoclimatic variations and the different biomes of Brazil can modify the relations between light interception and LAI; and consequently, modify the critical LAI. Thus, grazing management should be modified likewise (COÊLHO et al., 2014).

The stocking rate also is an important aspect of grazing management, because the adopted stocking rate above the pasture carrying capacity is one of the most determinant factors of pastureland degradation all over the country (GALDINO et al., 2013). DOURADO et al. (2019) evaluated the leaf blade dry mass of the tall-sized genotype 'IRI-381' in pastures under 2.0, 3.9, and 5.8 $\mathrm{AU} \mathrm{ha}^{-1}$ stocking rates and found values of $6,078,2,543$, and $1,670 \mathrm{~kg}$ $\mathrm{ha}^{-1}$, respectively. Moreover, the authors observed a decreasing from 31 to $15 \%$ of the leaf blades after pre-grazing, in the function of the stocking rate increase. In this case, the high grazing pressure negated the efficient pasture regrowth. Considering their morphophysiological adaptation against grazing pressure increases, short-sized genotypes present advantages compared to the tall-sized genotypes (CUNHA et al., 2007; VIANA et al., 2018).

In response to high grazing pressures and successive grazing cycles, the plants adapt and produce more aerial tillers that are shorter and lighter (CARVALHO et al., 2005). FERNANDES et al. (2016) evaluated the population density of aerial and basilar tillers in 'Mott' grass pastures under intermittent stocking and observed a substantial increase of aerial tiller population of around $167 \%$ (from 73.1 to 195.6 tillers $\mathrm{m}^{-2}$ ). Conversely, the increase of basilar tillers was only $62 \%$ (from 36.8 to 59.8 tillers $\mathrm{m}^{-2}$ ) after six grazing cycles.

Is worth pointing out that the low defoliation intensity in successive grazing cycles provides sub-grazing, which reduces the grazing efficiency and can negatively modify the nutritional value of harvested forage (SOLLENBERGER et al., 2020). In this sense, elephant grass pastures managed for a long time, in some cases, should be lowered below the post-grazing height for tiller renovation. This type of management can occur by mowing, which can increase the cost of production, or even by overgrazing with high stocking rates for a short occupation period (LIRA et al., 2010).

\section{Nitrogen fertilization and irrigation}

One of the most important factors of forage productivity reduction in pastures and cut-andcarry systems is the absence of nutrient deposition in the soil. In this situation, nitrogen $(\mathrm{N})$ is the mineral macronutrient most reported in the leaf tissues, and provides greater forage accumulation and tillering. The accumulation and forage mass responses to $\mathrm{N}$ fertilization can be linear (MARSCHNER, 2011).

However, management strategies related to defoliation frequency and intensity, besides $\mathrm{N}$ doses can alter the remobilization and the transport of this nutrient into the plants (LIU et al., 2011). Is worth 
considering that tall-sized elephant grass genotypes present high extractor capacity of minerals from the soil, due to its large growth rate (NOVAIS et al., 2007) In this sense, SILVA et al. (2015) evaluated the root chemical composition of elephant grass pastures fertilized with $\mathrm{N}$ doses of 0,150 and $300 \mathrm{~kg} \mathrm{ha}^{-1}$. The authors observed a decrease in root biomass as a function of $\mathrm{N}$ increase levels, from 370.3 to 202.7 $\mathrm{g} \mathrm{kg}^{-1} \mathrm{OM}$ after 512 days of incubation. Furthermore, the highest $\mathrm{N}$ level increased the root decomposition. Moreover, DOURADO et al. (2019) observed an increase of leaf productivity from 10.0 to $18.5 \mathrm{Mg}$ $\mathrm{ha}^{-1} \mathrm{DM}$ in an experiment with the same conditions and applied $\mathrm{N}$ levels. The authors emphasized the great $\mathrm{N}$ extraction capacity from the radicular system of the 'IRI-381' genotype.

Conversely, irrigation has been widely used in cut-and-carry systems and pastures of elephant grass, both to increase productivity and to reduce the seasonality of forage production (ARAÚJO et al., 2010; CARVALHO et al., 2018). Nevertheless, some parameters should be considered for the success of irrigation: (i) evapotranspiration of the soil-plant system; (ii) the relief; (iii) the quantity and the quality of water; (iv) estimation of the irrigation depth; and (v) uniformity of the applied water (ALENCAR et al., 2009). These technical parameters are important to avoid water deficit of the crop by drought or oversaturation, which reduce gas exchange and photosynthetic efficiency (KROTH et al., 2015). ARAÚJO et al. (2010) observed greater net photosynthesis for dwarf genotypes ('Mott', 'CNPGL 94-34-3', and 'CNPLG 92-198-7') in irrigated pastures $\left(20.0 \mu \mathrm{mol} \mathrm{m}{ }^{-2} \mathrm{~s}^{-1}\right)$ than in nonirrigated pastures $\left(8.0 \mu \mathrm{mol} \mathrm{m} \mathrm{m}^{-2} \mathrm{~s}^{-1}\right)$. Moreover, the authors observed a greater vapor pressure deficit in the irrigated pastures $(46 \mathrm{KPa})$ than that of nonirrigated $(36 \mathrm{KPa})$. According to the authors, the irrigation contributed to the photosynthesis increase and the reduction of evapotranspiration.

Conversely, the amount of water applied does not always result in better forage quality. CARVALHO et al. (2018) observed a linear decrease in the leaf percentage of purple elephant grass, from 59.33 to $50.67 \%$, as a function of the increase of water amount applied via irrigation, from zero to 700 $\mathrm{mm}$. Although, there was irrigation, the forage quality probably decreased because of the purple elephant grass growth rate.

\section{Use in the industrial sector}

The forage grasses present uses beyond animal feed in livestock. In recent years, the use of elephant grass clones for bioenergy production has increased. Elephant grass can be used as solid fuel in coal power plants, or even as raw material for advanced biofuels such as cellulolytic ethanol (MACHADO et al., 2017).In this context, tallsized genotypes stood out for their high dry matter productivity and the high fibrous carbohydrate content when the plant age is advanced. For this purpose, the genotypes with great stem proportion and thick stem diameter should be prioritized because the cellulose and lignin sources are concentrated in this morphological component (SINGH, 2013).

MINMUNIN et al. (2015) tested three methods of lignin extraction from Napier grass (tall-sized elephant grass) for cellulolytic ethanol production. The authors observed cellulose, hemicellulose, and lignin contents of $600.2 \mathrm{~g} \mathrm{~kg}^{-1}$, $238.0 \mathrm{~g} \mathrm{~kg}^{-1}$, and $82.0 \mathrm{~g} \mathrm{~kg}^{-1}$, respectively, when the plant heights varied from 3.0 to $4.0 \mathrm{~m}$. These results were obtained by lignin and cellulose removal from the produced biomass, which was high $(93.78 \%$ and $80.59 \%$, respectively) and provided high-quality ethanol. Moreover, elephant grass has the potential for synthetic wood manufacturing. BAKAR et al. (2017) observed only $27.83 \%$ of water absorption and only $6.67 \%$ of thickness expansion of synthetic fibers obtained from Napier grass. According to the authors, its fiber architecture forms a complex "mesh" in the stem, providing a high-quality fiber for its exploitation for this type of manufacturing.

\section{CONCLUSIONS}

The morphological aspects and the elephant grass size are important to direct its utilization in the different production systems. Scientific studies from recent decades suggested that tall-sized characteristics such as high forge mass and accumulation, organic reserves, a large number of basilar tillers, and stem elongation favor its management in cut-and-carry systems and its exploitation in industry sectors. Conversely, the shortsized genotypes present higher leaf proportions in the harvested forage, high leaf/stem ratios, and increased tillering. These factors facilitate its utilization in grazing systems.

\section{ACKNOWLEDGMENTS}

This study was financed in part by the Coordenação de Aperfeiçoamento de Pessoal de Nível Superior (CAPES), Brazil - Finance code 001, and by the Conselho Nacional de Desenvolvimento Científico e Tecnológico (CNPq). 


\section{DECLARATION OF CONFLICT OF INTEREST}

The authors declare no conflict of interest. The founding sponsors had no role in the design of the study; in the collection, analyses, or interpretation of data; in the writing of the manuscript, and in the decision to publish the results.

\section{AUTHORS' CONTRIBUTIONS}

The authors all equally contributed to the manuscript.

\section{REFERENCES}

ALENCAR, C. A. B. et al. Pasture irrigation: present and recommendations for use and management. Revista Brasileira de Zootecnia, v.38, p.98-108, 2009. Available from: $<$ https://doi. org/10.1590/S1516-35982009001300012>. Accessed: Mar. 20, 2020. doi: 10.1590/S1516-35982009001300012.

ANDRADE, E. A. et al. Herbage intake, methane emissions and animal performance of steers grazing dwarf elephant grass with or without access to Arachis pintoi pastures. Animal, v.10, n.10, p.1684-1688, 2016. Available from: <https://doi.org/10.1017 S1751731116000628>. Accessed: Mar. 20, 2020. doi: 10.1017/ S1751731116000628.

ARAÚJO, S. A. C. et al. Photosynthetic characteristics of dwarf elephant grass (Pennisetum purpureum SCHUM.) genotypes under different hydrics conditions. Acta Scientiarum. Animal Sciences, v.32, n.1, p.1-7, 2010. Available from: <https://doi.org/10.4025/ actascianimsci.v32i1.8961>. Accessed: Mar. 20, 2020. doi: 10.4025/actascianimsci.v32i1.8961.

BAKAR, N. A. et al. A techno-economical study on medium density fiberboard using Napier grass fiber as ceiling board. In: Proceedings of Mechanical Engineering Research Day, 2017. Cambridge: Woodhead Publishing, 2017. p.399-400.

BUDIMAN, B. et al. Morphological characteristics, productivity and quality of three napier grass (Pennisetum purpureum SCHUM) cultivars harvested at different age. Journal of the Indonesian Tropical Animal Agriculture, v.37, n.4, p.294-301, 2012. Available from: <https://doi.org/10.14710/ jitaa.37.4.294-301>. Accessed: Mar. 20, 2020. doi: 10.14710/ jitaa.37.4.294-301.

CARVALHO, A. P. S. et al. Agronomic features of elephant grass (Pennisetum purpureum SCHUM) cv. Roxo under irrigation. Semina: Ciências Agrárias, v.39, n.1, p.275-286, 2018. Available from: $\quad<$ http://dx.doi.org/10.5433/1679-0359.2018v39n1p275>. Accessed: Mar. 20, 2020. doi: 10.5433/1679-0359.2018v39n $1 \mathrm{p} 275$.

CARVALHO, C. A. B. et al. Morphogenesis of elephantgrass managed under two stubble heights post grazing. Boletim de Indústria Animal, v.62, n.1, p.45-54, 2005. Avaliable from: $<$ http://iz.sp.gov.br/bia/index.php/bia> . Accessed: Mar. 20, 2020.

COÊLHO, J. J. et al. Canopy height and its relationship with leaf area index and light interception in tropical grasses. Tropical Grasslands-Forrajes Tropicales, v.2, n.1, p.31-32, 2014. Avaliable from: <http://dx.doi.org/10.17138/TGFT(2)31-32>. Accessed: Mar. 20, 2020. doi: 10.17138/TGFT(2)31-32.
CUNHA, M. V. et al. Elephantgrass genotypes under grazing during the dry period in the Forest Zone of Pernambuco: factors related to grazing efficiency. Revista Brasileira de Zootecnia, v.36, n.2, p.291-300, 2007. Available from: <https://doi.org/10.1590/S151635982007000200004>. Accessed on: Oct. 27, 2020. doi: 10.1590/ S1516-35982007000200004.

CUNHA, M. V. et al. Association between the morphological and productive characteristics in the selection of elephant grass clones. Revista Brasileira de Zootecnia, v.40, n.3, p.482488, 2011. Available from: <https://doi.org/10.1590/S151635982011000300004>. Accessed: Mar. 20, 2020. doi: 10.1590/ S1516-35982011000300004.

DA SILVA, S. C.; NASCIMENTO JÚNIOR, D. Advances on research of tropical forage plants on pasturelands: morphophysiological characteristics and grazing management. Revista Brasileira de Zootecnia, v.36, n.especial, p.121138, 2007. Available from: <https://doi.org/10.1590/S151635982007001000014>. Accessed: Mar. 20, 2020. doi: 10.1590/ S1516-35982007001000014.

DOURADO, D. L. et al. Canopy structure and forage nutritive value of elephantgrass subjected to different stocking rate and $\mathrm{N}$ fertilization in the "Mata Seca" ecoregion of Pernambuco. Revista Brasileira de Zootecnia, v.48, p.1-13, 2019. Available from: $<$ https://doi.org/10.1590/rbz4820180134>. Accessed: Mar. 20, 2020. doi: $10.1590 /$ rbz4820180134.

FERNANDES, P. B. et al. Morphogenetic and structural characteristics of clones of elephant grass managed under intermittent stocking. Semina: Ciências Agrárias, v.37, n.4, p.2099-2110, 2016. Available from: $<$ https://doi.org/10.5433/16790359.2016v37n4p2099>. Accessed: Mar. 20, 2020. doi: $10.5433 / 1679-0359.2016 \mathrm{v} 37 \mathrm{n} 4 \mathrm{p} 2099$

GALDINO, S. et al. Classification of pasture degradation levels in terms of hydric erosion risk in Quartzipsamments areas at alto Taquari watershed (MS/MT, Brazil). Geografia, v.38, p.95-107, 2013. Available from: $<\mathrm{http}: / / \mathrm{www}$.periodicos.rc.biblioteca.unesp. br>. Accessed: Mar. 20, 2020

GASTAL, F.; LEMAIRE, G. Defoliation, shoot plasticity, sward structure and herbage utilization in pasture: review of the underlying ecophysiological processes. Agriculture, v.5, n.4, p.1146-1171, 2015. Available from: <https://doi. org/10.3390/agriculture5041146>. Accessed: Feb. 15, 2021. doi: 10.2989/10220119.2014.930929.

GOMIDE, C. A. M. et al. Structural traits of elephant grass (Pennisetum purpureum ScHUM.) genotypes under rotational stocking strategies. African Journal of Range \& Forage Science, v.32, n.1, p.51-57, 2015. Available from: $<$ https://doi.org /10.2989/10220119.2014.930929>. Accessed: Mar. 20, 2020. doi: $10.2989 / 10220119.2014 .930929$.

JORGENSEN, S. T. et al. Cultivar-by-cutting height interactions in Napier grass (Pennisetum purpureum ScHUMACH) grown in a tropical rain-fed environment. Acta Agriculturae Scandinavica Section B-Soil and Plant Science, v.60, n.3, p.199-210, 2010. Available from: <https://doi.org/10.1080/09064710902817954>. Accessed: Mar. 20, 2020. doi: 10.1080/09064710902817954.

KEBEDE, G. et al. Agronomic performance and nutritive values of Napier grass in the Central Highland of Ethiopia. Results of Livestock Research, p.17-30, 2016. Available 
from: $\quad<$ http://publication.eiar.gov.et:8080/xmlui/bitstream/ handle/123456789/3136>. Accessed: Mar. 20, 2020

KROTH, B. E. et al. Brachiaria brizantha cultivars grown under different water availability in Entisol. Revista Brasileira de Engenharia Agrícola e Ambiental, v.19, n.5, 2015. Available from: <https://doi.org/10.1590/1807-1929/agriambi. v19n5p464-469>. Accessed: Mar. 20, 2020. doi: 10.1590/18071929/agriambi.v19n5p464-469.

LEMAIRE, G. et al. Grassland productivity and ecosystem services. Oxford, UK : CABI, 2011. 284 p.

LIRA, M. A. et al. Elephant grass: fundamentals and perspectives. Recife, PE : IPA/UFRPE, 2010. 229p.

LIU, K. et al. Distribution of nutrients among soil-plant pools in 'Tifton 85 'bermudagrass pastures grazed at different intensities. Crop Science, v.51, n.4, p.1800-1807, 2011. Available from: $<$ https://doi.org/10.2135/cropsci2010.04.0209>. Accessed: Mar 20, 2020. doi: 10.2135/cropsci2010.04.0209.

MACHADO, J. C. et al. Elephant grass ecotypes for bioenergy production via direct combustion of biomass. Industrial Crops and Products, v.95, p.27-32, 2017. Available from: $<$ https://doi. org/10.1016/j.indcrop.2016.10.014>. Accessed: Mar. 20, 2020. doi: 10.1016/j.indcrop.2016.10.014

MARSCHNER, H. Marschner's mineral nutrition of higher plants. London, UK : Academic, 2011. 651p.

MINMUNIN, J. et al. Delignification of elephant grass for production of cellulosic intermediate. Energy Procedia, v.79, p.220-225, 2015. Available from: <https://doi.org/10.1016/j. egypro.2015.11.468>. Accessed: Mar. 20, 2020. doi: 10.1016/j. egypro.2015.11.468.

PACIULLO, D. S. C. et al. Morphogenesis and leaf biomass accumulation in elephantgrass sward evaluated at diferent period of the year. Pesquisa Agropecuária Brasileira, v.38, n.7, p.881887, 2003. Available from: <https://doi.org/10.1590/S0100204X2003000700013>. Accessed: Mar. 20, 2020. doi: 10.1590/ S0100-204X2003000700013.

PEDREIRA, C. G. S. Grazing methods. In: REIS, R.A. et al. Forragiculture: science, technology and management of forage resources. (Ed. 1). Jaboticabal, SP : Funep, 2013. p.481-495.

PEREIRA, A. V. et al. BRS Kurumi and BRS Capiaçu-New elephant grass cultivars for grazing and cut-and-carry system. Crop Breeding and Applied Biotechnology, v.17, n.1, p.59-62, 2017. Available from: $\quad<$ https://doi.org/10.1590/1984-70332017v17n1c9>. Accessed: Mar. 20, 2020. doi: 10.1590/1984-70332017v17n1c9.

QUEIROZ FILHO, J. L. et al. Production of dry matter and quality of elephant grass (Pennisetum purpureum, ScHUM). Revista Brasileira de Zootecnia, v.27, n.2, p.262-266, 1998. Available from: <https:// doi.org/10.1590/S1516-35982000000100010>. Accessed: Mar. 20, 2020. doi: 10.1590/S1516-35982000000100010.

QUEIROZ FILHO, J. L. et al. Dry matter production and quality of elephant grass (Pennisetum purpureum Schum.) cultivar roxo at different cutting ages. Revista Brasileira de Zootecnia, v.29, n.1, p.69-74, 2000. Available: <https://doi.org/10.1590/S151635982000000100010>. Accessed: Mar. 20, 2020. doi: 10.1590/ S1516-35982000000100010.
RIBEIRO, R. E. P. Establishment, productive and morphological responses of genotypes of Pennisetum sp. of different sizes under cutting and irrigation. 2019. 107f. Tese (Doutorado em Zootecnia)-Programa de Pós-graduação em Zootecnia, Universidade Federal Rural de Pernambuco.

SANCHÊS, S. S. C. et al. Quantitative anatomy and in situ ruminal degradation parameters of elephant grass under different defoliation frequencies. Revista Brasileira de Saúde e Produção Animal, v.19, n.2, p.166-177, 2018. Available from: <https://doi. org/10.1590/s1519-99402018000200003>. Accessed: Mar. 20, 2020. doi: 10.1590/s1519-99402018000200003.

SILVA, A. L. C. et al. Variability and heritability of morphologic characters in elephant grass clones in the Forest Zone in Pernambuco. Revista Brasileira de Zootecnia, v.39, n.10, p.21322140, 2010. Available from: <https://doi.org/10.1590/S151635982010001000005>. Accessed: Mar. 20, 2020. doi: 10.1590/ S1516-35982010001000005.

SILVA, H. M. S. et al. Stocking rate and nitrogen fertilization affect root decomposition of elephantgrass. Agronomy Journal, v.107, n.4, p.1331-1338, 2015. Available from: <https://doi.org/10.2134/ agronj14.0618>. Accessed: Mar. 20, 2020. doi: 10.2134/ agronj14.0618.

SINGH, B. P. Biofuel crops: production, physiology and genetics. (Ed). Oxford, UK : CABI, 2013. 631p.

SOLLENBERG, L. E. et al. Registration of 'Mott' dwarf elephantgrass. Crop Science, v.29, p.827-828, 1989. Available from: $<$ https://dl.sciencesocieties.org/publications $>$. Accessed: Mar. 20, 2020

SOLLENBERGER, L. E. et al. Pasture Design and Grazing Management. In: MOORE, K. J. et al. Forages: The Science of Grassland Agriculture Volume II. Chichester: Wiley Blackwell, 2020 p. 803-814.

SOUZA, P. H. et al. Nutritional value of elephant grass genotypes. Pesquisa Agropecuária Brasileira, v.52, n.10, p.951-955, 2017. Available from: <https://doi.org/10.1590/s0100204x2017001000016>. Accessed: Mar. 20, 2020. doi: 10.1590/ s0100-204x2017001000016.

TAIZ, L. et al. Plant physiology and development. Porto Alegre, RS: Artmed Editora, 2017. 811p.

TEAGUE, W. R. Forages and pastures symposium: Cover crops in livestock production: Whole-system approach: Managing grazing to restore soil health and farm livelihoods. Journal of Animal Science, v.96, n.4, p.1519-1530, 2018. Available from: <https:// doi.org/10.1093/jas/skx060>. Accessed: Oct. 27, 2020. doi: $10.1093 / \mathrm{jas} / \mathrm{skx} 060$.

VALADARES FILHO, S. C. et al. BR-CORTE 3.0. Calculation of nutritional requirements, formulation of diets and performance prediction of pure and crossbred Zebu cattle. 2016. Available from: <www.brcorte.com.br>. Accessed: Oct. $27,2020$.

VIANA, B. L. et al. Adaptability and stability analysis for selection of elephantgrass clones under grazing. Crop Science, v.55, n.2, p.950-957, 2015. Available from: <https://doi.org/doi:10.2135/ cropsci2014.05.0406>. Accessed: Mar. 20, 2020. doi: 10.2135/ cropsci2014.05.0406. 
VIANA, B. L. et al. Morphological characteristics and proportion of leaf blade tissues of elephant grass clones under sheep grazing. Pesquisa Agropecuária Brasileira, v.53, n.11, p.12681275, 2018. Available from: <https://doi.org/10.1590/s0100204x2018001100009>. Accessed: Mar. 20, 2020. doi: 10.1590/ s0100-204x2018001100009.

WILLIAMS, M. J.; HANNA, W. W. Performance and nutritive quality of dwarf and semi-dwarf elephantgrass genotypes in the south-eastern USA. Tropical Grasslands, v.29, p.122-122, 1995. Available from: <http://tropicalgrasslands.info/public/journals. html>. Accessed: Jul. 29, 2020.

ZEWDU, T. Effect of plant density on morphological characteristics, yield and chemical composition of Napier grass (Pennisetum purpureum ScHUM.). East African Journal of Sciences, v. 2, n. 1, p.5561,2008. Available from:<https://doi.org/10.4314/eajsci.v2i1.40365>. Accessed: Mar. 20, 2020. doi: 10.4314/eajsci.v2i1.40365. 